\title{
Gonadotropin-Releasing Hormone and NMDA Receptor Gene Expression and Colocalization Change during Puberty in Female Rats
}

\author{
Andrea C. Gore, T. J. Wu, Jacob J. Rosenberg, and James L. Roberts \\ Fishberg Research Center for Neurobiology, Mount Sinai Medical Center, New York, New York 10029
}

During development, an increase in gonadotropin-releasing hormone $(\mathrm{GnRH})$ release occurs that is critical for the initiation of puberty. This increase is attributable, at least in part, to activation of the $\mathrm{GnRH}$ neurosecretory system by inputs from neurotransmitters, such as glutamate, acting via NMDA receptors. We examined changes in $\mathrm{GnRH}$ and NMDA-R1 gene expression by RNase protection assay of preoptic area-anterior hypothalamic (POA-AH) dissections of female rats undergoing normal puberty or in which precocious puberty was induced by treatment with the glutamate agonist NMA. GnRH mRNA levels increased significantly throughout normal development; this was accelerated by treatment with NMA. NMDA-R1 mRNA levels increased only between P10 and P20. The acceleration of the elevation in $\mathrm{GnRH}$ mRNA levels by NMDA suggests that a stimulation of $\mathrm{GnRH}$ gene expression may be a rate-limiting factor for the onset of puberty. This is attributable to a posttranscriptional mechanism because $\mathrm{GnRH}$ primary transcript levels, an index of proGnRH gene transcription, were not observed to change during puberty. Alterations in the colocalization of $\mathrm{GnRH}$ neurons with the NMDA-R1 subunit during puberty also were assessed immunocytochemically. The percentage of $\mathrm{GnRH}$ neurons that double-labeled with NMDA-R1 was $2 \%$ in prepubertal rats and $3 \%$ in pubertal rats; this increased to $19 \%$ in postpubertal rats. Taken together, these studies suggest that an increase in glutamatergic input to $\mathrm{GnRH}$ neurons plays a role in the increase in $\mathrm{GnRH}$ release and gene expression that occurs at the initiation of puberty.

Key words: NMDA; puberty; GnRH; rat; RNase protection assay; immunocytochemistry
The release of gonadotropin-releasing hormone $(\mathrm{GnRH})$ from neuroterminals in the median eminence is low during the juvenile period in mammals. GnRH release increases at the onset of puberty; this is thought to be the rate-limiting factor for the initiation of puberty, because pulsatile infusion of $\mathrm{GnRH}$ to prepubertal animals induces precocious puberty (Wildt et al., 1980; Urbanski and Ojeda, 1987). Because the GnRH neurosecretory system is already morphologically and functionally mature long before the onset of puberty (Silverman et al., 1982; Goldsmith and Song, 1987), it is probable that changes in inputs to the $\mathrm{GnRH}$ system are responsible for the increase in pulsatile $\mathrm{GnRH}$ release that ultimately results in the attainment of adult reproductive function. For example, increases in stimulatory inputs from noradrenergic (Advis et al., 1978; Raum et al., 1980; Gore and Terasawa, 1991), neuropeptide Y (Sutton et al., 1988; Minami et al., 1990; Gore et al., 1993; Gruaz et al., 1993), and glutamatergic (Gay and Plant, 1987; Urbanski and Ojeda, 1990) neurons precede the onset of puberty. Similarly, a decrease in inhibition

\footnotetext{
Received March 21, 1996; revised June 3, 1996; accepted June 4, 1996.

This work was supported by National Institutes of Health Grants DK08743 to A.C.G. and DK39029 to J.L.R. This report was made possible in part by funds granted to A.C.G. via a fellowship program sponsored by the Charles H. Revson Foundation. All animal experiments were conducted in accord with Guidelines for the Care and Use of Experimental Animals, using protocols approved by the Institutional Animal Care and Use Committee at Mount Sinai School of Medicine (Grants 91-353 NB and 95-285 NB). We thank Robert Woolley for photographic assistance, William Janssen and Shouyee Yung for expert technical support, and Deanna Benson and Adam Gazzaley for aid with microscopy. The statements made and views expressed are solely the responsibility of the authors.

Correspondence should be addressed to Dr. Andrea C. Gore, Fishberg Research Center for Neurobiology, Mount Sinai Medical Center, P.O. Box 1065, New York, NY 10029

Copyright (C) 1996 Society for Neuroscience $0270-6474 / 96 / 165281-09 \$ 05.00 / 0$
}

from GABAergic neurons probably also contributes to the timing of puberty (Mitsushima et al., 1994). However, the cellular and molecular mechanisms involved in mediating the effects of neuroactive substances on GnRH neurons at the onset of puberty are primarily unknown, and it is crucial to study these mechanisms to understand the process by which $\mathrm{GnRH}$ release increases at the onset of puberty.

There are numerous cellular/molecular levels at which neuroactive substances can cause an increase in $\mathrm{GnRH}$ release during puberty, including transcription of the proGnRH gene, posttranscriptional regulation such as mRNA stability, and posttranslational mechanisms such as processing of the GnRH prohormone, as well as secretion itself. Our laboratory and others have reported previously that changes in the steroid or neurotransmitter environment can result in increases in cytoplasmic GnRH mRNA levels (Petersen et al., 1991, 1996; Liaw and Barraclough, 1993; Gore and Roberts, 1994, 1995) independent of transcription of the GnRH gene (Gore and Roberts, 1994, 1995). This suggests that GnRH mRNA levels are regulated to a large extent by a post-transcriptional mechanism such as mRNA stability. We also found in mice that GnRH cytoplasmic mRNA levels and nuclear primary transcript levels increase during development, but with a different time course (Gore et al., 1995), indicating an uncoupling of transcriptional and post-transcriptional processes.

In the present study, we investigated the cellular and molecular mechanisms associated with the pubertal increase in GnRH release. We addressed the following questions: (1) Is an increase in GnRH gene mRNA levels associated with the pubertal increase in $\mathrm{GnRH}$ release at the onset of puberty? (2) Is this a transcriptional or post-transcriptional event? (3) When precocious puberty is 
induced by NMA, does this accelerate any observed changes in GnRH gene expression? (4) Do NMDA receptor mRNA levels change during puberty? (5) Does glutamate act directly on NMDA receptors on GnRH neurons, and does this change during puberty?

\section{MATERIALS AND METHODS}

\section{Animals}

Female Sprague Dawley rats aged postnatal day (P) 21-41 or timedpregnant rats were purchased from Harlan Sprague Dawley (Indianapolis, IN). Animals were housed three per cage in a temperature-controlled room with a $12 \mathrm{hr}$ light, $12 \mathrm{hr}$ dark cycle (lights on at 7:00 A.M.). Food and water were available ad libitum.

\section{Experimental design}

Experiment I: changes in GnRH and NMDA-R1 gene expression during puberty. Rats aged P10, P20, P25, P29-P31, P30-P32, P34-P36, P35-P37, and $\mathrm{P} 41(n=6-8 \mathrm{rats} /$ group $)$ were used in this study. For ages P10, P20, and $\mathrm{P} 25$, rats were killed by decapitation. The other rats were injected with either NMA (40 mg/kg, s.c.) or saline vehicle twice daily at 1:00 P.M. and 3:00 P.M., beginning on P25, and monitored for vaginal opening (VO) and first diestrus (D). Injections were discontinued on VO. Rats and their age-matched counterparts were killed on the day of VO (P29P31 for NMA-injected rats and P34-P36 for control rats), D (P30-P32 for NMA and P35-P37 for controls), or P41. Brains were removed, and the preoptic area-anterior hypothalamus (POA-AH) was dissected as described previously (Jakubowski and Roberts, 1992; Gore and Roberts, 1994) with a stainless steel brain slicer (model RBM-4000C, Activational Systems, Warren, MI), snap-frozen in liquid Freon on dry ice, and stored at $-80 \mathrm{C}$.

Experiment II: neuroanatomical distribution of GnRH neurons and NMDA-R1 subunit. Rats aged $\mathrm{P} 21, \mathrm{P} 36$ (day of VO), or $\mathrm{P} 41(n=$ $3-4 /$ group) were anesthetized deeply with chloral hydrate $(500 \mathrm{mg} / \mathrm{kg})$ and perfused intracardially with $3 \mathrm{ml}$ of saline followed by $60 \mathrm{ml}$ of $4 \%$ paraformaldehyde. Brains were removed and post-fixed for $4-6 \mathrm{hr}$ in $4 \%$ paraformaldehyde and then transferred to $0.05 \mathrm{M}$ phosphate buffer (PB) for storage at $4 \mathrm{C}$. Sections $(40 \mu \mathrm{m})$ were cut on a vibratome (Ted Pella, Redding, CA) and stored in PB containing sodium azide (0.5\%).

\section{$R N A$ extraction and RNase protection assay}

RNA from frozen POA-AH dissections was extracted as described previously (Jakubowski and Roberts, 1992; Gore and Roberts, 1994). Cytoplasmic and nuclear RNA was suspended in $20 \mu \mathrm{l}$ of hybridization solution (0.1 M EDTA, $\mathrm{pH} 8$, and $4 \mathrm{~m}$ guanidine thiocyanate; final $\mathrm{pH} 7.5$ ) for RNase protection assay. The following DNA subclones were used as probes: (1) GnRH complementary (c) DNA (cGnRH), 362 base pairs (bp) in length, spanning the HindIII site in exon 1 to the BamHI site in exon 4, and subcloned into a pBS(+) vector (Stratagene, La Jolla, CA); (2) cyclophilin (1B15) cDNA, $111 \mathrm{bp}$, spanning from the PstI and XmnI restriction sites, and subcloned in a Bluescript $\mathrm{KS}(+)$ vector; (3) a proGnRH genomic fragment covering $506 \mathrm{bp}$ of the intron B-exon 3-intron $\mathrm{C}$ junction (B3C) and subcloned in the EcoRI and HindIII sites of a pBS(+) vector; (4) an NMDA-R1 cDNA clone complementary to 284 bp of the N terminus, spanning the Bam HI and HindIII restriction sites, and subcloned into Bluescript KS(+) vector; this clone was kindly provided by Dr. Stuart Sealfon (Mount Sinai Medical Center, New York, NY).

Solution hybridization/RNase protection was performed as described previously (Jakubowski and Roberts, 1992; Gore and Roberts, 1994). Briefly, cGnRH, B3C, and NMDA-R1 probes were labeled with $\left[\alpha^{32} \mathrm{P}\right] \mathrm{UTP}$ to high specific activity $(\sim 1,300,000 \mathrm{cpm} / \mathrm{ng})$ and $1 \mathrm{~B} 15$ probe was labeled to low specific activity $(\sim 60,000 \mathrm{cpm} / \mathrm{ng})$ in a final volume of $25 \mu \mathrm{l}(20 \mu \mathrm{l}$ of RNA and $5 \mu \mathrm{l}$ of probe). Cytoplasmic samples were incubated with cGnRH, NMDA-R1, and 1B15 probes in the same tubes. For standard curves, probes were mixed with increasing known amounts of cGnRH $(0-1.25 \mathrm{pg}), 1 \mathrm{~B} 15(0-250 \mathrm{pg})$, B3C $(0-0.5 \mathrm{pg})$, or NMDA (0-100 pg) reference RNAs. Samples (POA-AH RNA) and standards were allowed to hybridize for $16-18 \mathrm{hr}$ at $30 \mathrm{C}$; the remainder of the assay was conducted as described previously (Jakubowski and Roberts, 1992; Gore and Roberts, 1994). Gels were exposed to x-ray film for 18-36 hr to produce an autoradiogram and to a phosphor-imaging screen (Molecular Dynamics, Sunnyvale, CA) for $18 \mathrm{hr}$ for quantitation. The amount of radioactivity in each sample was determined by comparison with the amount of reference RNA calculated by regression analysis.
Table 1. Age (postnatal day) of rats at vaginal opening and first diestrus

\begin{tabular}{llll} 
& NMA & Control & $p$ \\
\hline Vaginal opening & $30.0 \pm 0.2$ & $34.6 \pm 0.3$ & 0.0001 \\
Diestrus & $31.0 \pm 0.3$ & $35.8 \pm 0.4$ & 0.0001
\end{tabular}

Rats were injected with NMA or saline (control) twice daily beginning on P25. NMA treatment caused a significant advancement in the timing of vaginal opening and first diestrus as compared with saline injection.

\section{Immunocytochemistry}

Fluorescent immunocytochemistry was performed with the rabbit polyclonal antibody to GnRH [SW-1; kindly provided by Dr. Susan Wray (Wray et al., 1988)] and the mouse monoclonal antibody to NMDA-R1 [54.1; kindly provided by Dr. John Morrison (Siegel et al., 1994; Huntley et al., 1994)]. Sections were washed with PB for 5 min and then with PB plus $2 \%$ normal goat serum plus $2 \%$ normal horse serum for 20 min. Primary antibodies (1:250 for 54.1 and 1:2000 for SW-1) were added and incubated for $2 \mathrm{~d}$ at $4 \mathrm{C}$. Then, sections were washed three times for 10 min in PB. The secondary antibodies (goat anti-rabbit Texas Red for SW-1 and goat anti-mouse FITC for 54.1) at concentrations of 1:200 were added and incubated for 2-4 hr. Sections then were washed three times for 5-10 min in PBS. Sections were mounted onto gelatin-subbed slides and coverslipped (Gel/Mount, Fisher Scientific, Springfield, NJ).

\section{Analyses}

The amount of GnRH and NMDA-R1 mRNA in POA-AH dissections in Experiment I was normalized to cyclophilin mRNA levels in the same sample to minimize gel-loading variation, as described previously (Gore and Roberts, 1994, 1995). Changes in levels of RNAs were compared across development by two-way ANOVA, followed by Fisher's protected least significant difference (PLSD) post hoc test. Significance was set at $p<0.05$.

In Experiment II, sections stained for GnRH and NMDA-R1 subunit were examined with a Zeiss Axiophot Fluorescence Microscope equipped with the appropriate filters for visualization of the fluorescent signals. In this study, every sixth section was immunostained and evaluated. Each GnRH neuron initially was identified and counted by scanning each tissue section from the rostral to caudal extent of each brain at $200 \times$ and scored as NMDA-R1-positive or -negative at $400 \times$. These results were recorded onto sequential atlas reproductions in the rostral to caudal axis (Paxinos, 1986). Colocalization of GnRH and NMDA-R1 immunostaining within a cell was identified by fluorescent microscopy, using different fluorophores linked to the specific antibodies. Omission of the primary antibodies, or preabsorption of the primary antibody with $2 \mu \mathrm{g}$ of $\mathrm{GnRH}$ before application to the tissue, was used in control experiments. Adjacent sections also were processed for only one primary antibody and then examined with the inappropriate filter to check for bleed-through of the fluorophores. Subsequent to this data collection, the sections were reexamined at $630 \times$, using a Plan-Neofluor $63 \times / 1.25$ numerical aperture (N.A.) oil objective. Images were collected with a Zeiss LSM 410 inverted confocal microscope; a suitable contrast/brightness setting that yielded a high-resolution image for the cells was determined and used to produce the images. The stored images then were transferred to Adobe Photoshop 3.0 (Macintosh) and printed with a phaser printer (Tektronics). The occurrence of NMDA-R1-positive GnRH neurons for each rat was expressed as a percentage of the total number of GnRH neurons. Differences in mean percentage of NMDA-R1-positive GnRH neurons were determined by one-way ANOVA, followed by Fisher's PLSD post hoc test for comparisons between groups. The level of significance was set at $p<0.05$.

\section{RESULTS}

\section{Experiment I: changes in GnRH and NMDA-R1 gene expression during puberty}

Effects of NMA on the timing of the onset of puberty

Repeated injections of NMA beginning on P25 caused a significant advance in the timing of vaginal opening (VO; $p<0.0001$ ) and first diestrus ( $\mathrm{D} ; p<0.0001)$ as compared with injection of saline vehicle (Table 1). VO occurred at P30.0 $\pm 0.2 \mathrm{~d}$ of age in the NMA-treated group, compared with P34.6 $\pm 0.3 \mathrm{~d}$ in control 


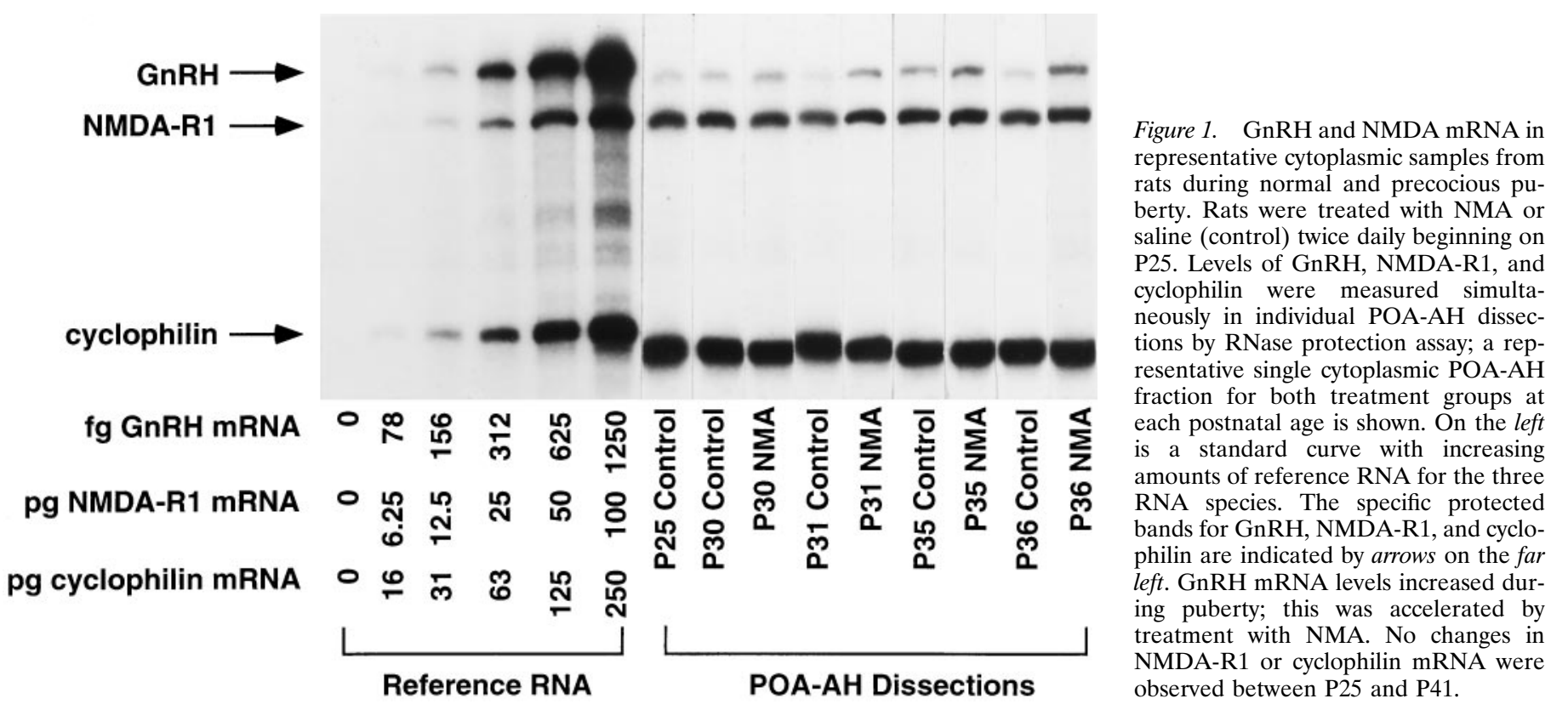

rats. D occurred at P31.0 $\pm 0.3 \mathrm{~d}$ for the NMDA-treated group and at P35.8 $\pm 0.4 \mathrm{~d}$ in the saline-treated group.

\section{GnRH cytoplasmic $m R N A$ levels}

Representative examples of GnRH, NMDA-R1, and cyclophilin mRNA in individual POA-AH dissections are shown in Figure 1.
GnRH mRNA levels increased gradually but significantly during development between P10 and P41 in control rats (Fig. 2). Two-way ANOVA indicated that there was a significant effect of age $(p<$ $0.05)$ and treatment $(p<0.0001)$ on GnRH mRNA levels. Post hoc analysis indicated significant increases in cytoplasmic GnRH mRNA levels in control rats between P10 and P20, P31 and the day of VO

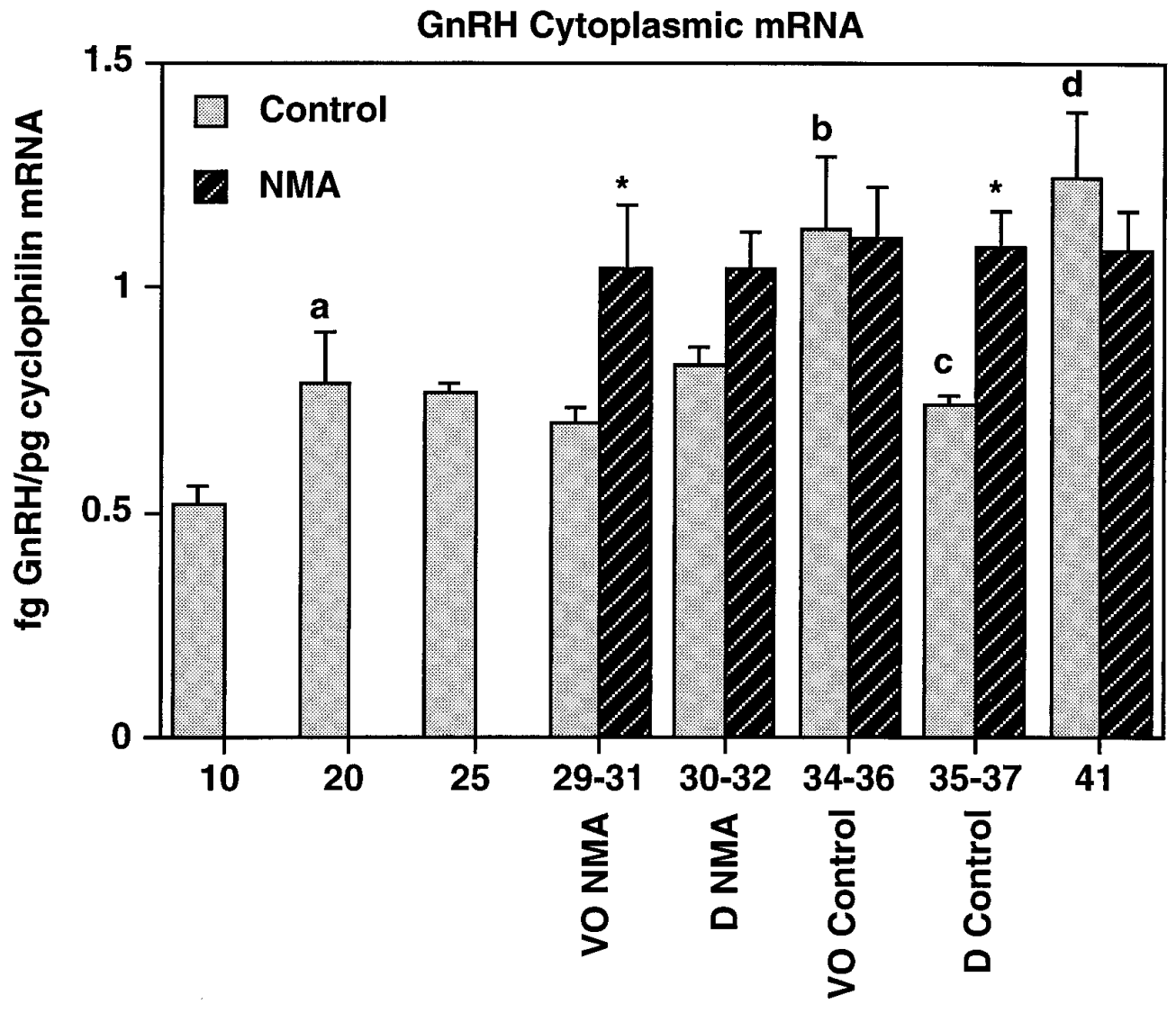

Age (days)
Figure 2. GnRH cytoplasmic mRNA levels increase during puberty; this is accelerated by treatment with NMA. GnRH mRNA levels (normalized to cyclophilin) were analyzed in rats from P10 to P41 treated with NMA or saline (control). The days of vaginal opening $(V O)$ and first diestrus $(D)$ for each group are indicated below the $x$-axis. GnRH mRNA levels increased significantly during puberty in control rats $(p<0.05)$. This was accelerated significantly by treatment with NMA $(p<$ 0.0001 ). Levels of GnRH mRNA were increased significantly, as compared with those of the previous day analyzed at P20, the day of VO (P34-P46), and P41. Levels declined significantly between the day of VO (P34-P36) and first diestrus (P35-P37). GnRH mRNA levels were significantly higher in the NMA-treated group as compared with their age-matched control at VO (P29P31) and P36. $n=6-8$ /group. $a, p<$ 0.05 versus $\mathrm{P} 10 ; b, p<0.05$ versus control $\mathrm{P} 30-\mathrm{P} 32 ; c, p<0.05$ versus control $\mathrm{P} 34-\mathrm{P} 36 ; d, p<0.05$ versus control $\mathrm{P} 35-\mathrm{P} 37 ;{ }^{*} p<0.05$ versus corresponding control. 
Figure 3. GnRH primary transcript in representative nuclear samples from rats during normal and precocious puberty. Levels of GnRH primary transcript were measured in individual POA-AH dissections by RNase protection assay; a representative single nuclear POA-AH fraction for both treatment groups at each postnatal age is shown. On the left is a standard curve with increasing amounts of reference RNA for the B3C probe. The specific protected band is indicated by the arrow on the far left. GnRH primary transcript levels did not increase during puberty, nor were they affected by treatment with NMA.

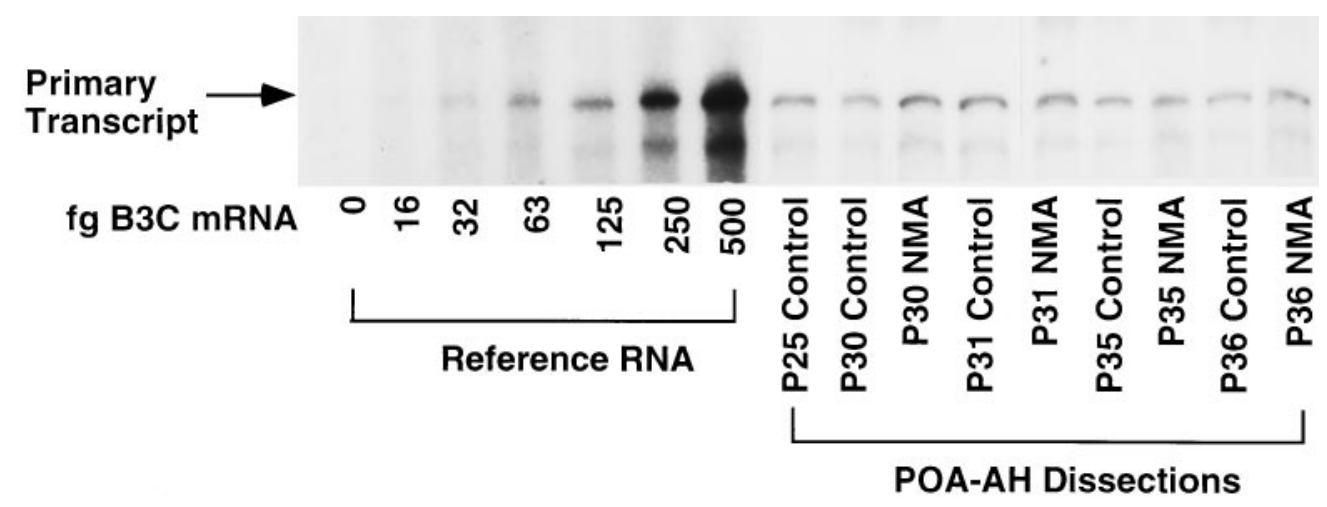

in control rats $(\sim \mathrm{P} 35)$, and the day of first diestrus $(\sim \mathrm{P} 36)$ and P41. A significant decrease in GnRH mRNA levels was observed between VO $(\sim \mathrm{P} 35)$ and $\mathrm{D}(\sim \mathrm{P} 36)$. Treatment with NMA twice daily beginning on P25 resulted in GnRH mRNA levels significantly above control levels at the day of VO for NMA-treated rats $(\sim \mathrm{P} 30)$ and $\mathrm{D}$ for control rats $(\sim \mathrm{P} 36 ; p<0.05)$.

GnRH primary transcript levels

A representative RNase protection assay showing $\mathrm{GnRH}$ primary transcript in individual POA-AH dissections (nuclear fraction) is shown in Figure 3. Two-way ANOVA indicated that levels of GnRH primary transcript did not change during development from P10 to P41 ( $p=0.635$; Fig. 4 ) and that treatment with NMA had no significant effect on GnRH primary transcript levels ( $p=$ 0.092).

\section{NMDA-R1 mRNA levels}

NMDA-R1 subunit mRNA levels increased significantly in control rats only from $\mathrm{P} 10$ to $\mathrm{P} 20$ ( $p<0.01$; Fig. 5). A representative RNase protection assay showing levels of NMDA-R1 mRNA in individual POA-AH dissections is shown in Figure 1. Treatment with NMA had no effect on NMDA-R1 mRNA levels $(p=0.225)$.

\section{Experiment II: neuroanatomical distribution of $\mathrm{GnRH}$ neurons and NMDA-R1 subunit}

Immunofluorescent GnRH and NMDA-R1-positive neurons were detected in the rostro-caudal extent in the POA-AH in all rats examined. In this study, every sixth section was immunostained and evaluated; GnRH neurons were localized in regions of the rat brain consistent with previous reports of GnRH neuro-
Figure 4. GnRH nuclear primary transcript levels do not change during puberty or by treatment with NMDA. GnRH primary transcript levels were analyzed in rats from $\mathrm{P} 10$ to $\mathrm{P} 41$ treated with NMA or saline (control). See Figure 2 for description of axes and treatments. GnRH primary transcript levels did not change significantly during development and were unaffected by treatment with NMA. $n=6-8$ /group.

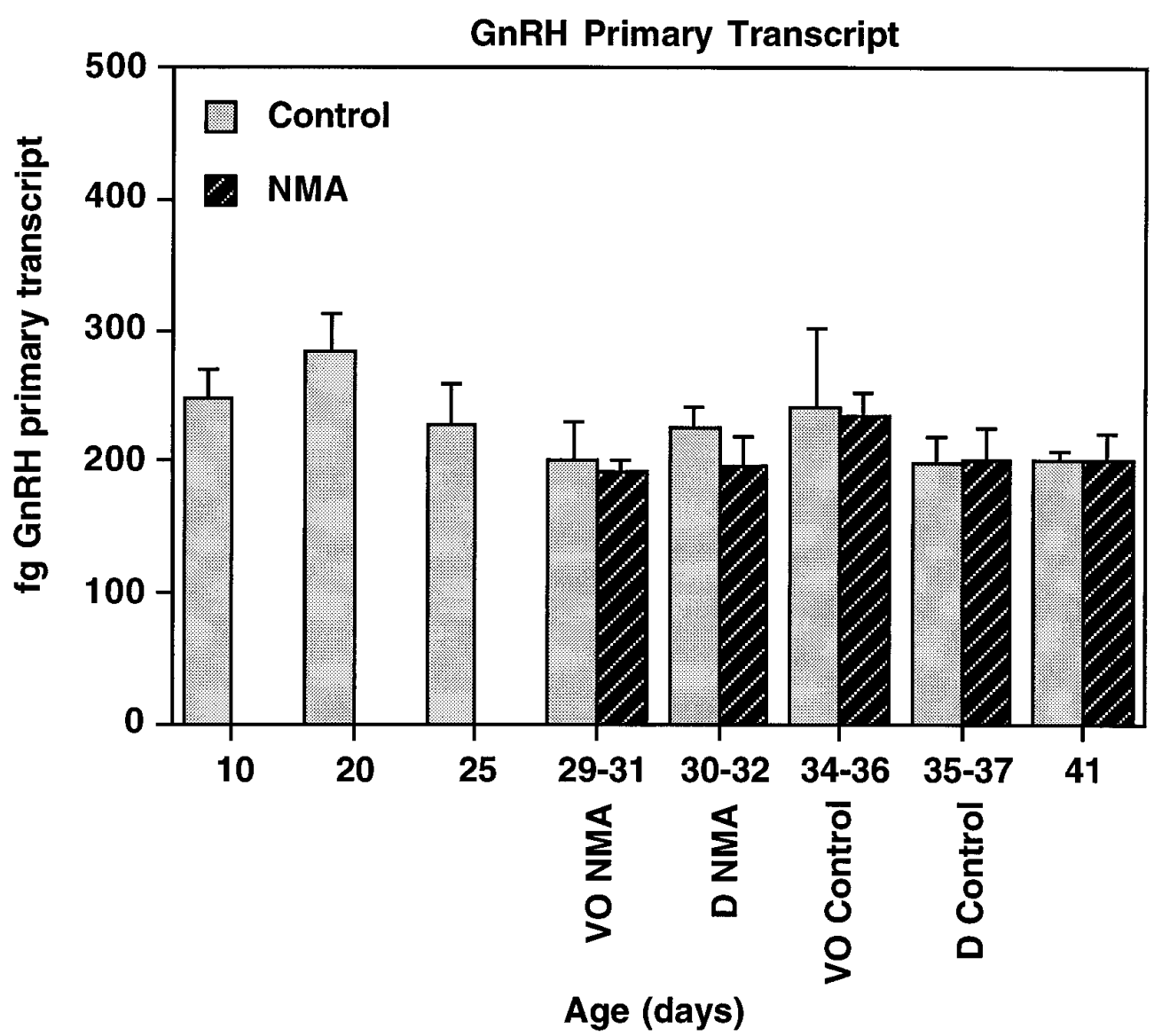




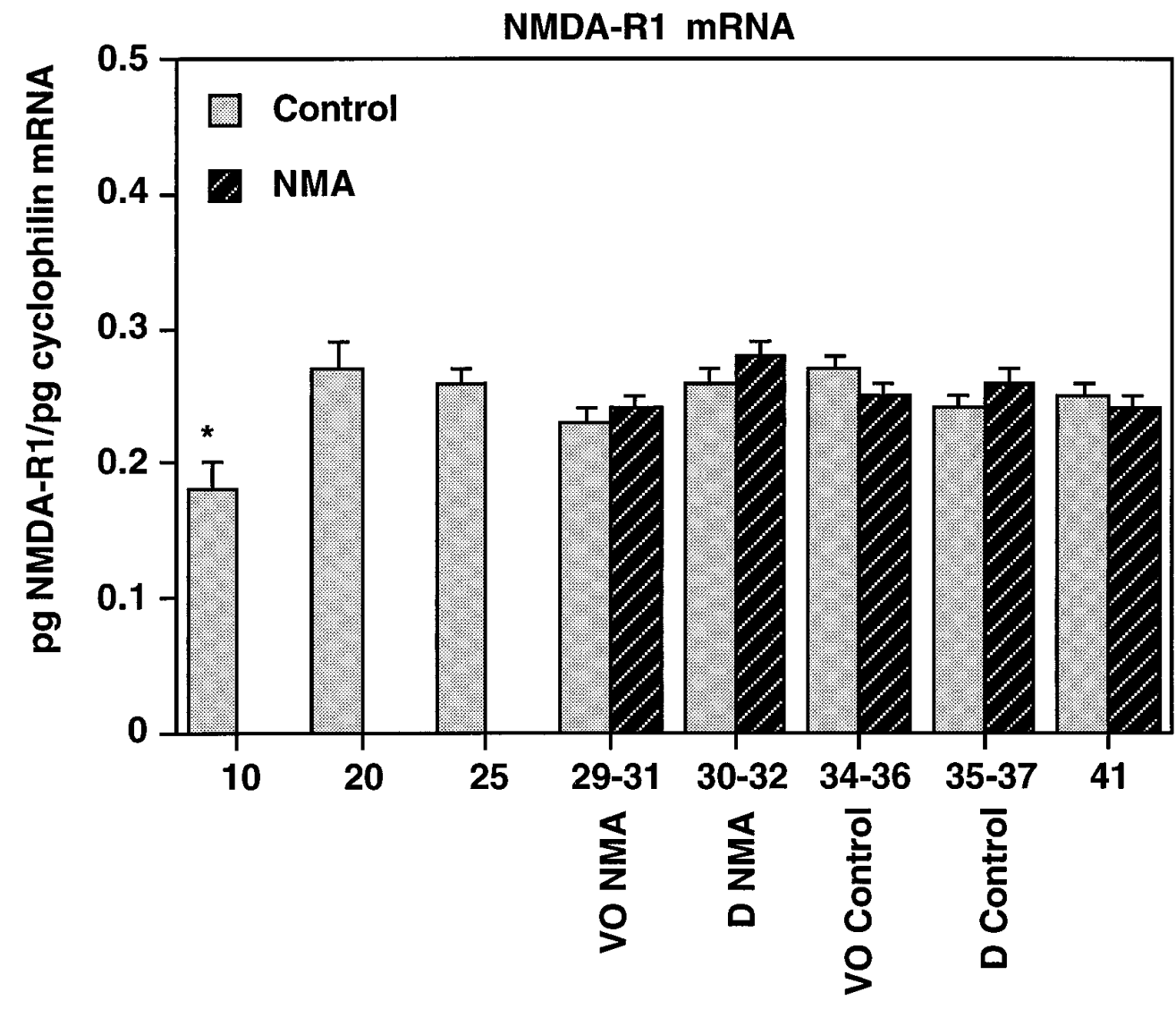

Age (days)

nal distribution (Witkin et al., 1982). Expression of detectable NMDA-R1 in GnRH neurons increased significantly from the prepubertal (P21) and pubertal (day of VO, P36) to the postpubertal (P41) stage in these female rats $(p<0.01$; Table 2$)$. Representative examples of GnRH-positive neurons, some double-labeled for the NMDA receptor, are shown in a postpubertal rat in Figure 6. Regardless of the level of expression, neurons that contain both GnRH and NMDA-R1 were seen consistently in the region of the OVLT/POA and only occasionally were seen in the regions caudal to the OVLT/POA or the septal regions. The rostro-caudal distribution of $\mathrm{GnRH}$ neurons that are double-labeled with NMDA-R1 is mapped in Figure 7.

\section{DISCUSSION}

In the present study, we found that changes in glutamatergic inputs to GnRH neurons may play a critical role in the initiation of puberty. Furthermore, we have elucidated some of the cellular/ molecular mechanisms by which glutamate exerts its actions on GnRH neurons. In Experiment I, we investigated changes in GnRH gene expression during normal and precocious puberty. In normally developing female rats, GnRH mRNA levels increase gradually from $\mathrm{P} 10$ to $\mathrm{P} 41$, confirming previous reports (Jakubowski et al., 1991; Dutlow et al., 1992). Our present detailed analysis of changes in GnRH mRNA levels indicates that they increase significantly on the day of vaginal opening (VO). Thus, the elevation in release of GnRH peptide that occurs at and is critical to the onset of puberty probably reflects increases in biosynthesis of the decapeptide. The decrease in GnRH mRNA levels observed between VO and D in the present study is con-
Figure 5. NMDA-R1 mRNA levels increase from P10 to P20 but do not change during puberty. NMA-R1 mRNA levels were analyzed in rats from P10 to P41 treated with NMA or saline (control). See Figure 2 for description of axes and treatment. NMDA-R1 mRNA levels increased significantly between P10 and P20; no further changes were observed during development. Treatment with NMA had no effect on NMDA-R1 mRNA levels in the POA-AH. ${ }^{*} p<0.05$ versus all other days; $n=6-8$ /group. sistent with the observation in adult-cycling female rats that GnRH mRNA levels are low on diestrus (Zoeller and Young, 1988; Park et al., 1990; Gore and Roberts, 1995). We studied the mechanism for these changes in GnRH mRNA levels by measuring GnRH primary transcript levels, an index of gene transcription (Yeo et al., 1996). Because GnRH primary transcript levels do not change between P10 and P41, the elevation in GnRH mRNA levels probably is attributable to a post-transcriptional mechanism such as an enhancement in GnRH mRNA stability, i.e., a decrease in degradation of GnRH mRNA. A similar phenomenon was reported for cycling female rats on diestrus II (Gore and Roberts, 1995) and in male rats administered NMA (Gore and Roberts, 1994); thus, post-transcriptional changes in GnRH mRNA levels probably represent a crucial mechanism by which $\mathrm{GnRH}$ gene expression is regulated by neurotransmitters and steroids and during development. That this mechanism is not universal during development, however, is exemplified by the proopiomelanocortin system in which primary transcript and mature mRNA increase in parallel (Scott et al., 1990).

The increase in GnRH mRNA levels during puberty occurs at an earlier age in rats given repeated injections of NMA at the prepubertal stage. Thus, stimulation of NMDA receptors on GnRH neurons or on interneurons causes an activation of the GnRH system at the mRNA level. Because this occurs posttranscriptionally, as repeated injections of NMA cause no change in $\mathrm{GnRH}$ primary transcript levels, it is possible that factors in the cytoplasm involved in stabilizing the mRNA or preventing its degradation are affected by activation of NMDA receptors. The 
Table 2. Expression of NMDA-R1 subunit in GnRH neurons as detected by immunocytochemistry

\begin{tabular}{|c|c|c|c|}
\hline & $\begin{array}{l}\text { Total \# } \\
\text { GnRH } \\
\text { neurons } \\
\text { counted }\end{array}$ & $\begin{array}{l}\text { \# NMDA- } \\
\text { R1-positive } \\
\text { GnRH } \\
\text { neurons }\end{array}$ & $\begin{array}{l}\% \text { NMDA- } \\
\text { R1-positive } \\
\text { GnRH } \\
\text { neurons }\end{array}$ \\
\hline \multicolumn{4}{|c|}{ Prepubertal (P21) } \\
\hline A3 & 48 & 1 & 2 \\
\hline A5 & 63 & 2 & 3 \\
\hline A21 & 82 & 0 & 0 \\
\hline A20 & 79 & 1 & 1 \\
\hline Mean \pm SEM & $68 \pm 8$ & $1 \pm 0.4$ & $2 \pm 0.6$ \\
\hline \multicolumn{4}{|c|}{ Pubertal (Day of VO:P36) } \\
\hline A24 & 52 & 1 & 2 \\
\hline A25 & 68 & 2 & 3 \\
\hline A26 & 46 & 2 & 4 \\
\hline A27 & 73 & 3 & 4 \\
\hline Mean $\pm \mathrm{SEM}$ & $60 \pm 6$ & $2 \pm 0.4$ & $3 \pm 0.5$ \\
\hline \multicolumn{4}{|c|}{ Postpubertal (P41) } \\
\hline A6 & 60 & 18 & 30 \\
\hline A7 & 50 & 13 & 26 \\
\hline A28 & 67 & 6 & 9 \\
\hline A31 & 61 & 11 & 12 \\
\hline Mean \pm SEM & $60 \pm 4$ & $12 \pm 2 *$ & $19 \pm 5^{*}$ \\
\hline
\end{tabular}

The number of GnRH neurons that were double-labeled with the NMDA-R1 subunit was determined in prepubertal, pubertal (day of vaginal opening), and postpubertal rats. The identification number of each rat is indicated on the left Although few GnRH neurons were double-labeled in prepubertal and pubertal rats, this increased significantly in postpubertal rats.

${ }^{*} p<0.01$ versus prepubertal and pubertal.

concept that NMDA acts at a post-transcriptional level in $\mathrm{GnRH}$ neurons is supported further by the observation that treatment of rats with NMDA did not stimulate expression of cFos, a putative indicator of gene activation (transcription), in GnRH neurons (Saitoh et al., 1991; Lee et al., 1993). Furthermore, the rapidity with which NMDA stimulates acute increases in GnRH mRNA levels in adult rats (Petersen et al., 1991; Liaw and Barraclough, 1993; Gore and Roberts, 1994) indicates a more rapidly regulated mechanism than transcription, such as mRNA stability.

We observed an increase in NMDA-R1 mRNA levels in the POA-AH between P10 and P20. This finding is in agreement with that of another group (Nyberg et al., 1995), who reported a similar increase in female rats between P15 and P20. NMDA-R1 mRNA levels increase at a slightly different age, between P20 and P25, in the arcuate nucleus/median eminence (Nyberg et al., 1995). Other non-neuroendocrine brain regions exhibit differential developmental patterns of NMDA-R1 mRNA expression: increases of this transcript were reported between P3 and P15, and P15 and P67 in frontal cortex and hippocampus (Franklin et al., 1993). In cerebellum and brain stem, NMDA-R1 mRNA levels did not change between P3 to P15, whereas increases were observed between P15 and P67 (Franklin et al., 1993). Consistent with our finding, it has been reported that the ability of female rats to respond to injections of NMDA with an increase in luteinizing hormone $(\mathrm{LH})$ release is observed first at P15 (MacDonald and Wilkinson, 1992). Furthermore, activation of NMDA receptors for $5 \mathrm{~d}$ with a single daily injection of NMDA $(20 \mathrm{mg} / \mathrm{kg})$ between P21 and 25 or P24 and 28 was sufficient to induce precocious VO, whereas giving NMDA between P16 and P20 did not affect the timing of VO (Smyth and Wilkinson, 1994). This age limitation may be attributable to the fact that the NMDA receptor system on
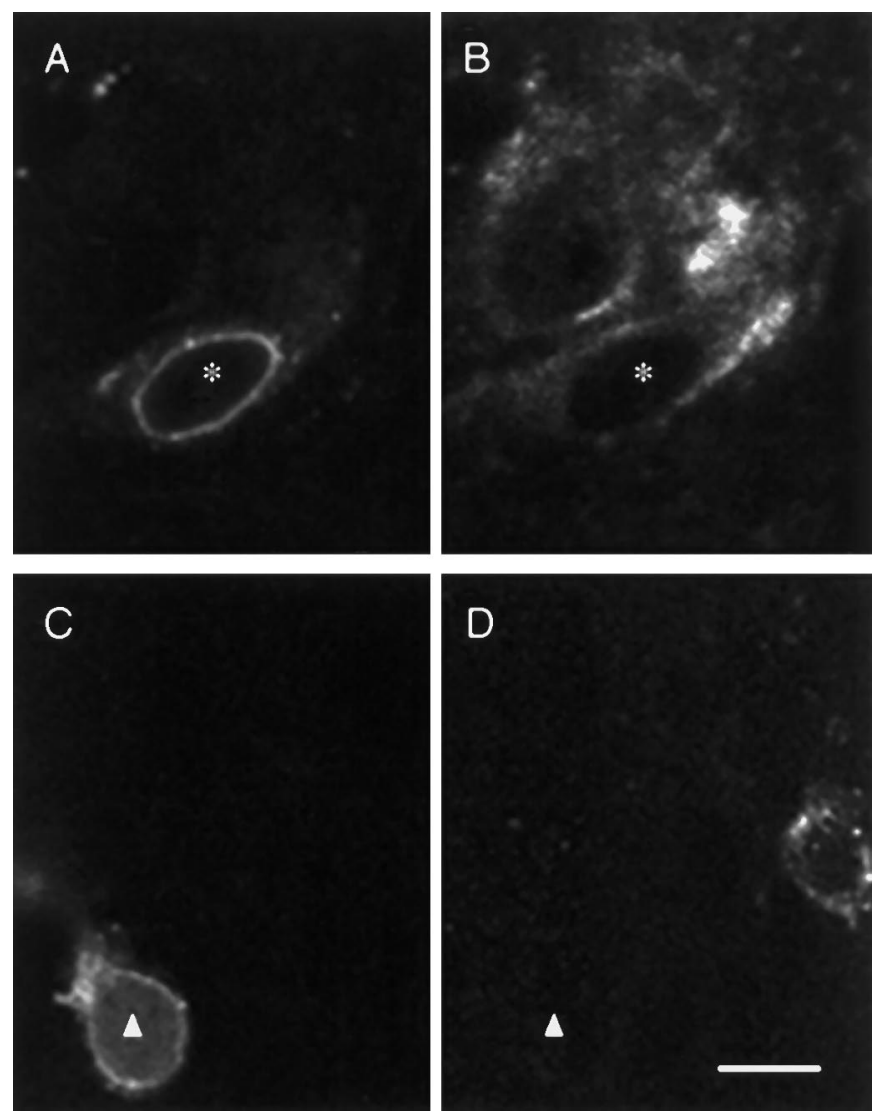

Figure 6. GnRH neuron double-labeling with the NMDA-R1 subunit in a postpubertal rat. Double-immunolabeling of $\mathrm{GnRH}$ neurons with the NMDA-R1 subunit in a postpubertal rat. $A, B$, Images from the same section stained for GnRH and NMDA-R1 immunoreactivity, respectively. A neuron double-labeled for the two antigens is marked by the asterisk; another NMDA-R1-positive neuron that does not immunostain for GnRH is seen in $B$, also. $C, D$, Images from the same section stained for GnRH and NMDA-R1, respectively. A neuron with detectable GnRH but not NMDA-R1 immunoreactivity is indicated by the triangle. The two GnRH-positive neurons depicted in $A$ and $C$ are representative of others observed in this study in that they demonstrated intense perinuclear staining. Bar in $D, 10 \mu \mathrm{m}$.

GnRH and/or interneurons is not established sufficiently, i.e., NMDA receptors are deficient in number or function; therefore, application of exogenous NMDA is ineffective in stimulating precocious puberty before P21. The finding that NMDA-R1 mRNA levels are in the process of increasing in the POA-AH between P10 and P20 supports this hypothesis.

Another limitation that would prevent exogenous NMDA from stimulating precocious $\mathrm{VO}$ when it is administered between P16 and P20 is that endogenous inhibitory inputs to GnRH neurons, for example from the GABA system, may be quite strong before puberty and that this inhibition must be removed before stimulatory inputs from glutamatergic and other systems increase $\mathrm{GnRH}$ release sufficiently to result in the onset of puberty. This is supported by the finding that GABA levels are elevated before puberty and decrease at the onset of puberty (Mitsushima et al., 1994). Changes in the overall inhibitory and excitatory tone from inputs of neurotransmitters, trophic factors, and steroids probably all combine to coordinate the timing of the onset of puberty.

The results of Experiment II indicate an anatomical site for glutamate action on the GnRH neurosecretory system and demonstrate the presence of the NMDA-R1 subunit on GnRH neu- 


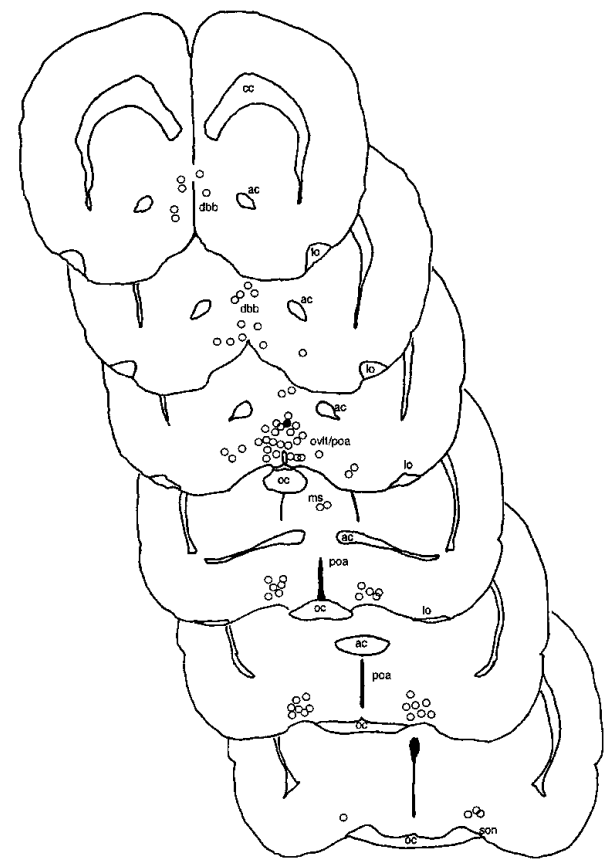

a. Prepubertal (P21)

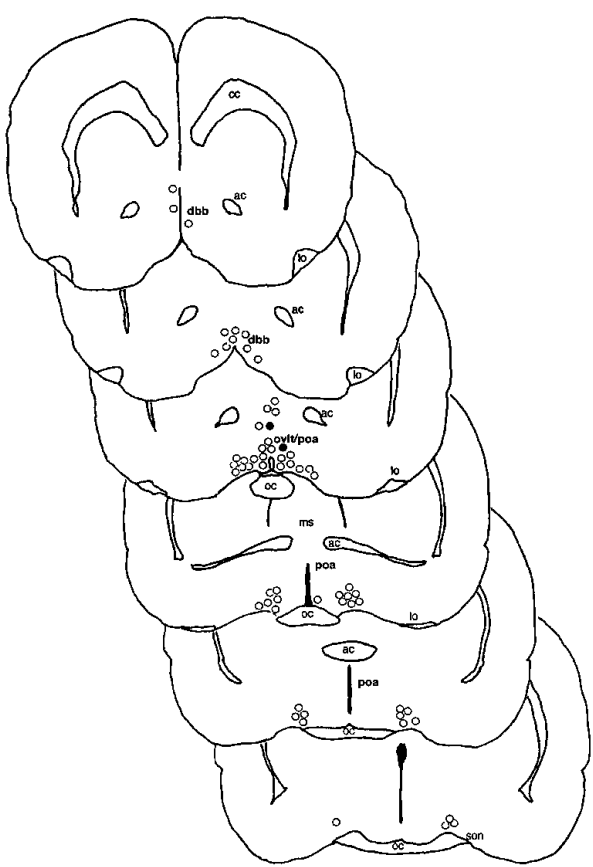

b. Pubertal (Day of VO; P36)

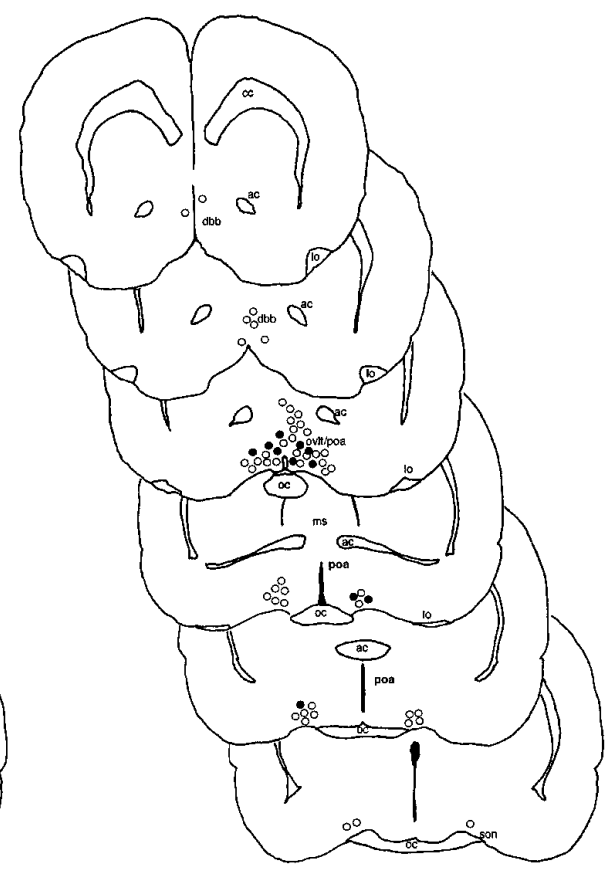

c. Postpubertal (P41)

Figure 7. Rostro-caudal representation of GnRH neurons double-labeling with NMDA-R1. The rostro-caudal distribution of double-labeled neurons was determined in a representative prepubertal (A21; $\mathrm{P} 21 ; a)$, pubertal (A25; day of vaginal opening; $b$ ), and postpubertal (A31; P41; $c$ ) rat. A series of sections from the level of the diagonal band of Broca to the rostral hypothalamic level, illustrating GnRH neurons containing $(\bullet)$ or not containing $(\circ)$ detectable NMDA-R1 subunit immunoreactivity, is presented. The sections represented in $a-c$ show detectable NMDA-R1 subunit immunoreactivity in GnRH neurons in the region of the OVLT and caudal, with the highest expression in the postpubertal animal. $a c$, Anterior commissure; $d b b$, diagonal band of Broca; $c c$, corpus callosum; lo, lateral olfactory tubercle; poa, preoptic area; $m s$, medial septum; oc, optic chiasm; ovlt, organum vasculosum of the lamina terminalis; son, supraoptic nucleus.

rons in the developing female rat brain. The R1 subunit confers the ability to bind the ligand; thus, its presence indicates the potential for a functional NMDA receptor (Monyer et al., 1992; Nakanishi, 1992). Although the colocalization of NMDA receptors previously has not been established on GnRH neurons in the rat (Abbud and Smith, 1995) and hamster (Urbanski et al., 1995), preliminary reports have confirmed our findings in the rat POA-AH (Ulibarri et al., 1994; Eyigor and Jennes, 1995). Also, it is well established that GT1 cells, a mouse hypothalamic tumorderived cell line that has many properties of GnRH neurons (Mellon et al., 1990), express NMDA receptors (Mahachoklertwattana et al., 1994; Spergel et al., 1994), and so it is possible that GnRH neurons in the mouse brain also express the NMDA receptor. The presence of NMDA-R1 subunit on GnRH neurons in rats indicates that at least some of the effects of glutamate on $\mathrm{GnRH}$ release and gene expression occur directly on GnRH neurons, although it is probable that glutamate also may exert indirect effects via interneurons contacting GnRH neurons.

To our knowledge, this is the first report focusing on the expression of NMDA-R1 on GnRH neurons during pubertal development. Our results show that the expression of NMDA-R1 on GnRH neurons increases significantly from the prepubertal to the postpubertal period. This finding is intriguing in light of the observation that synaptogenesis in the hypothalamus increases markedly during puberty (Matsumoto and Arai, 1977; Marani et al., 1981), suggesting the likelihood of an increase in glutamatergic synapses on GnRH neurons. Furthermore, synaptogenesis is accelerated in animals that are administered monosodium glutamate, which activates glutamate receptors (Marani et al., 1982); thus, in the present study, repeated injections of NMA may accelerate this synaptogenesis. However, because the alteration in detectable NMDA-R1 subunit on GnRH neurons is not observed until after the onset of puberty, it is likely that this developmental increase in colocalization plays a role in events subsequent to the onset of puberty, such as the development of adult estrous cycles. This remains to be determined. Also, it has been reported that, whereas the total number of GnRH neurons does not change during postnatal development, the morphological appearance of these neurons shifts from a smooth to an irregular contour (Wray and Hoffman, 1986a,b). This irregular shape of GnRH neurons may result in an increased surface area, thereby allowing for a greater number of synaptic inputs from glutamate and other neurons.

The GnRH neurons that double-label with the NMDA-R1 receptor subunit seem to be concentrated in the OVLT/POA. Several experiments, including electrochemical stimulation (Everett et al., 1964) and deafferentation or lesion studies (Samson and McCann, 1979; Wise et al., 1981; Kalra and Kalra, 1983), have demonstrated that this is an important region for the induction of an LH surge and ovulation. Other studies have suggested that there may exist a primary subpopulation of GnRH neurons localized in this same region that is crucial for producing higher levels of GnRH in times of greater demand, e.g., the LH surge (Rubin et al., 1994; King et al., 1995). This subpopulation of GnRH neurons may be under developmental regulation, and it is quite possible that those neurons that express the NMDA receptor represent a phenotypically distinct subpopulation of GnRH neu- 
rons. These may subserve the induction of puberty as well as the maintenance of reproductive cycles in the adult female rat.

\section{REFERENCES}

Abbud R, Smith MS (1995) Do GnRH neurons express the gene for the NMDA receptor? Brain Res 690:117-120.

Advis JP, Simpkins JW, Chen HT, Meites J (1978) Relation of biogenic amines to onset of puberty in the female rat. Endocrinology 103:11-16.

Dutlow CM, Rachman J, Jacobs TW, Millar RP (1992) Prepubertal increases in gonadotropin-releasing hormone mRNA, gonadotropinreleasing hormone precursor, and subsequent maturation of precursor processing in male rats. J Clin Invest 90:2496-2501.

Everett JW, Radford HM, Holsinger J (1964) Electrolyte irritative lesions in the hypothalamus and other forebrain areas: effects on luteinizing hormone release and the ovarian cycle. In: Hormonal steroids (Martini L, Pecile A, eds), pp 235-254. New York: Academic.

Eyigor O, Jennes L (1995) Immunocytochemical localization of gonadotropin-releasing hormone, glutamate, and kainate-2 receptor protein in rat brain. Soc Neurosci Abstr 21:1889.

Franklin SO, Elliott K, Zhu Y-S, Wahlestedt C, Inturrisi CE (1993) Quantitation of NMDA receptor (NMDA-R1) mRNA levels in the adult and developing rat CNS. Mol Brain Res 19:93-100.

Gay VL, Plant TM (1987) N-methyl-D,L-aspartate (NMA) elicits hypothalamic GnRH release in prepubertal male rhesus monkeys (Macaca mulatta). Endocrinology 120:2289-2296.

Goldsmith PC, Song T (1987) The gonadotropin-releasing hormone containing ventral hypothalamic tract in the fetal rhesus monkey (Macaca mulatta). J Comp Neurol 237:130-149.

Gore AC, Roberts JL (1994) Regulation of gonadotropin-releasing hormone gene expression by the excitatory amino acids kainic acid and $N$-methyl-D,L-aspartate in the male rat. Endocrinology 134:2026-2031.

Gore AC, Roberts JL (1995) Regulation of gonadotropin-releasing hormone gene expression in the rat during the luteinizing hormone surge. Endocrinology 136:889-896.

Gore AC, Terasawa E (1991) A role for norepinephrine in the control of puberty in the female rhesus monkey, Macaca mulatta. Endocrinology 129:3009-3017.

Gore AC, Blum M, Roberts JL (1995) Developmental changes in mouse GnRH gene expression: transcriptional and post-transcriptional regulation. Soc Neurosci Abstr 21:264.

Gore AC, Mitsushima D, Terasawa E (1993) A possible role of neuropeptide $\mathrm{Y}$ in the control of the onset of puberty in female rhesus monkeys. Neuroendocrinology 58:23-34.

Gruaz NM, Pierroz DD, Rohner-Jeanrenaud F, Sizonenko PC, Aubert ML (1993) Evidence that neuropeptide Y could represent a neuroendocrine inhibitor of sexual maturation in unfavorable metabolic conditions in the rat. Endocrinology 133:1891-1894.

Huntley GW, Vickers JC, Janssen W, Brose N, Heinemann SF, Morrison JH (1994) Distribution and synaptic localization of immunocytochemically identified NMDA receptor subunit proteins in sensory-motor and visual cortices of monkey and human. J Neurosci 14:3603-3619.

Jakubowski M, Roberts JL (1992) Multiplex solution hybridization-ribonuclease protection assay for quantitation of different ribonucleic acid transcripts from snap-frozen neuroendocrine tissues of individual animals. J Neuroendocrinol 4:79-89.

Jakubowski M, Blum M, Roberts JL (1991) Postnatal development of gonadotropin-releasing hormone and cyclophilin gene expression in the female and male rat brain. Endocrinology 128:2702-2708.

Kalra SP, Kalra PS (1983) Neural regulation of luteinizing hormone secretion in the rat. Endocr Rev 4:311-351.

King JC, Tai DW, Hanna IK, Pfeiffer A, Haas P, Ronsheim PM, Mitchell SC, Turcotte JC, Blaustein JD (1995) A subgroup of LHRH neurons in guinea pigs with progestin receptors is centrally positioned within the total population of LHRH neurons. Neuroendocrinology 61:265-275.

Lee W-S, Abbud R, Hoffman GE, Smith MS (1993) Effects of $N$-methylD-aspartate receptor activation on $\mathrm{cFos}$ expression in luteinizing hormone-releasing hormone neurons in female rats. Endocrinology 133:2248-2254.

Liaw J-J, Barraclough CA (1993) $N$-methyl-D,L-aspartic acid differentially affects LH release and LHRH mRNA levels in estrogen-treated ovariectomized control and androgen-sterilized rats. Mol Brain Res 17:112-118.

MacDonald MC, Wilkinson M (1992) Characterization and ontogenesis of $N$-methyl-D-aspartate-evoked luteinizing hormone secretion in immature female rats. J Neuroendocrinol 4:223-229.
Mahachoklertwattana P, Sanchez J, Kaplan SL, Grumbach MM (1994) $N$-methyl-D-aspartate (NMDA) receptors mediate the release of gonadotropin-releasing hormone $(\mathrm{GnRH})$ by NMDA in a hypothalamic GnRH neuronal cell line (GT1-1). Endocrinology 134:1023-1030.

Marani E, Rietveld WJ, Boon ME, Gerrits NM (1981) Fluorescencedisplacement from the median eminence toward the arcuate nucleus at puberty. Histochemistry 73:165-169.

Marani E, Rietveld WJ, Boon ME (1982) Monosodium glutamate accelerates migration of hypothalamic perikarya at puberty. Histochemistry 75:145-150.

Matsumoto A, Arai Y (1977) Precocious puberty and synaptogenesis in the hypothalamic arcuate nucleus in pregnant mare serum gonadotropin (PMSG)-treated immature female rats. Brain Res 129:375-378.

Mellon PL, Windle JJ, Goldsmith PC, Padula CA, Roberts JL, Weiner RI (1990) Immortalization of hypothalamic GnRH neurons by genetically targeted tumorigenesis. Neuron 5:1-10.

Minami S, Frautschy SA, Plotsky PM, Sutton SW, Sarkar DK (1990) Facilitatory role of neuropeptide $\mathrm{Y}$ on the onset of puberty: effect of immunoneutralization of neuropeptide $\mathrm{Y}$ on the release of luteinizing hormone and luteinizing hormone-releasing hormone. Neuroendocrinology 52:112-115.

Mitsushima D, Hei DL, Terasawa E (1994) Gamma-aminobutyric acid is an inhibitory neurotransmitter restricting the release of luteinizing hormone-releasing hormone before the onset of puberty. Proc Natl Acad Sci USA 91:395-399.

Monyer H, Sprengel R, Schoepfer R, Herb A, Higuchi M, Lomeli H, Burnashev N, Sakmann B, Seeburg PH (1992) Heteromeric NMDA receptors: molecular and functional distinction of subtypes. Science 256:1217-1221.

Nakanishi S (1992) Molecular diversity of glutamate receptors and implications for brain function. Science 258:597-603.

Nyberg CL, Srivastava V, Hiney J, Lara F, Dees WL (1995) $N$-methylD-aspartic acid receptor mRNA levels and luteinizing hormone release in immature female rats: effects of stage of pubertal development and exposure to ethanol. Endocrinology 136:2874-2880.

Park O-K, Gugneja S, Mayo KE (1990) Gonadotropin-releasing hormone gene expression during the rat estrous cycle: effects of pentobarbital and ovarian steroids. Endocrinology 127:365-372.

Paxinos (1986) The rat brain in stereotaxic coordinates. San Diego: Academic.

Petersen SL, McCrone S, Keller M, Gardner E (1991) Rapid increases in LHRH mRNA levels following NMDA. Endocrinology 129:1679-1681.

Petersen SL, Gardner E, Adelman J, McCrone S (1996) Examination of steroid-induced changes in LHRH gene transcription using ${ }^{33} \mathrm{P}$ - and ${ }^{35}$ S-labeled probes specific for intron 2. Endocrinology 137:234-239.

Raum WJ, Glass AR, Swerdloff RS (1980) Changes in hypothalamic catecholamine neurotransmitters and pituitary gonadotropins in the immature female rat: relationships to the gonadostat theory of puberty onset. Endocrinology 106:1253-1258.

Rubin BS, Lee CE, King JC (1994) A reduced proportion of luteinizing hormone (LH)-releasing hormone neurons express Fos protein during the preovulatory or steroid-induced LH surge in middle-aged rats. Biol Reprod 51:1264-1272.

Saitoh Y, Silverman A-J, Gibson MJ (1991) Norepinephrine neurons in mouse locus coeruleus express c-fos protein after $N$-methyl-D,L-aspartic acid (NMDA) treatment: relation to LH release. Brain Res 561:11-19.

Samson WK, McCann SM (1979) Effects of lesions in the organum vasculosum of the lamina terminalis on the hypothalamic distribution of luteinizing hormone-releasing hormone and gonadotropin secretion in the ovariectomized rat. Endocrinology 105:939-946.

Scott REM, Autelitano DJ, Lugo DI, Blum M, Roberts JL, Pintar JE (1990) Developmental changes in levels of pro-opiomelanocortin intron A-containing heterogeneous nuclear RNA and mature messenger RNA in the anterior and neurointermediate lobes of the rat pituitary. Mol Endocrinol 8:812-820.

Siegel SJ, Brose N, Janssen WG, Gasic GP, Jahn R, Heinemann SF, Morrison JH (1994) Regional, cellular, and ultrastructural distribution of the glutamate receptor subunit NMDA-R1 in monkey hippocampus. Proc Natl Acad Sci USA 91:564-568.

Silverman A-J, Antunes JL, Abrams GM, Nilaver G, Thau R, Robinson JA, Ferin M, Krey LC (1982) The luteinizing hormone-releasing hormone pathways in rhesus (Macaca mulatta) and pigtailed (Macaca nemestrina) monkeys: new observations on thick, unembedded sections. J Comp Neurol 211:309-317. 
Smyth C, Wilkinson M (1994) A critical period for glutamate receptormediated induction of precocious puberty in female rats. J Neuroendocrinol 6:275-284.

Spergel DJ, Krsmanovic LZ, Stojilkovic SS, Catt KJ (1994) Glutamate modulates $\left[\mathrm{Ca}^{2+}\right]_{\mathrm{i}}$ and gonadotropin-releasing hormone secretion in immortalized hypothalamic GT1-7 neurons. Neuroendocrinology 59:309-317.

Sutton SW, Mitsugi N, Plotsky PM, Sarkar DK (1988) Neuropeptide Y (NPY): a possible role in the initiation of puberty. Endocrinology 123:2152-2154.

Ulibarri C, Cao Z, Akesson TR (1994) Estrogen regulates GluR1 mRNA in GnRH immunoreactive neurons of the rat. Soc Neurosci Abstr 20:92.

Urbanski HF, Ojeda SR (1987) Activation of luteinizing hormonereleasing hormone release advances the onset of female puberty. Neuroendocrinology 46:273-276.

Urbanski HF, Ojeda SR (1990) A role of $N$-methyl-D-aspartate (NMDA) receptors in the control of $\mathrm{LH}$ secretion and initiation of female puberty. Endocrinology 126:1774-1776.

Urbanski HF, Garyfallou VT, Kohama SG, Munro G, Lee C (1995) Do LHRH neurons of male Syrian hamster express glutamate receptors? Soc Neurosci Abstr 21:1889.

Wildt L, Marshall G, Knobil E (1980) Experimental induction of puberty in the infantile rhesus monkey. Science 207:1373-1375.
Wise PM, Rance N, Selmanoff MK, Barraclough CA (1981) Changes in radioimmunoassayable LHRH in discrete brain areas of the rat at various times on proestrous, diestrous day 1 , and after phenobarbital administration. Endocrinology 108:2179-2185.

Witkin JW, Paden CM, Silverman A-J (1982) The luteinizing hormonereleasing hormone (LHRH) system in the rat brain. Neuroendocrinology 35:429-438.

Wray S, Hoffman G (1986a) A developmental study of the quantitative distribution of LHRH neurons within the central nervous system of postnatal male and female rats. J Comp Neurol 252:522-531.

Wray S, Hoffman G (1986b) Postnatal morphological changes in rat LHRH neurons correlated with sexual maturation. Neuroendocrinology 43:93-97.

Wray S, Gahwiler BH, Gainer H (1988) Slice cultures of LHRH neurons in the presence and absence of brainstem and pituitary. Peptides 9:1151-1175.

Yeo TTS, Gore AC, Jakubowski M, Dong K, Blum M, Roberts JL (1996) Characterization of GnRH gene transcripts in a mouse hypothalamic neuronal GT1 cell line. Mol Brain Res, in press.

Zoeller RT, Young WS, III (1988) Changes in cellular levels of messenger ribonucleic acid encoding gonadotropin-releasing hormone in the anterior hypothalamus of female rats during the estrous cycle. Endocrinology 123:1688-1689. 